Volume 1 Issue 2, September 2017: pp. 180-195. Copyright (C) 2017 HOLREV. Faculty of Law, Halu Oleo University, Kendari, Southeast Sulawesi, Indonesia. ISSN: 2548-1762 | e-ISSN: 2548-1754. Open Access at: http://ojs.uho.ac.id/index. php/holrev/

\title{
Tinjauan Yuridis Kewenangan Komisi Pemberantasan Korupsi Melakukan Penyidikan Penggabungan Perkara Tindak Pidana Korupsi dan Pencucian Uang
}

\author{
Legal Analysis the Power of Corruption Eradication Commission on \\ Investigation of Case Combination on Corruption and Money Laundering
}

\author{
Sabrina Hidayat \\ Dosen Fakultas Hukum Universitas Halu Oleo \\ E-mail: sabrina.hidayat54@yahoo.com
}

\begin{abstract}
Corruption Eradication Commission (KPK) initially has no power to investigate on Money Laundering. Subsequently, in the advance of criminal procedural law, it evidently has the power to investigate the money laundering which is originally such a criminal act of corruption. Therefore, corruption eradication commission has integrated the phase of investigation by started for investigating the source of a criminal act in the form of criminal corruption as the authority and power of corruption eradication commission. The integration between cases of corruption and money laundering finally brought out the consequences of combining the cases toward the phase of the prosecution on the money laundering, on the one hand, and criminal corruption, on the other hand, by sticking to the principle of concursus (continuous act).
\end{abstract}

Keyword: the power of KPK, combining cases, corruption, money laundering

\begin{abstract}
Abstrak: Pada awalnya Komisi Pemberantasan Korupsi tidak berwenang melakukan penyidikan tindak pidana pencucian uang yang berdiri sendiri. Selanjutnya dalam perkembangan ilmu hukum acara pidana, penyidikan ternyata dapat menelusuri tindak pidana pencucian uang yang tindak pidana asalnya dari tindak pidana korupsi yang sedang disidik tersebut. Dengan demikian, penggabungan perkara pada tahap penyidikan oleh Komisi Pemberantasan Korupsi telah dilakukan yang dimulai dengan penyidikan tindak pidana asal berupa tindak pidana korupsi yang secara yuridis normatif merupakan kewenangan Komisi Pemberantasan Korupsi. Penggabungan perkara tindak pidana korupsi dengan tindak pidana pencucian uang pada tahap penyidikan yang dilakukan oleh Komisi Pemberantasan Korupsi membawa konsekuensi penggabungan perkara pada tahap penuntutan terhadap tindak pidana pencucian uang dengan tindak pidana asalyang berupa tindak pidana korupsi dengan tetap berpegang pada prinsip concursus.
\end{abstract}

Kata kunci: Kewenangan KPK, Gabungan Perkara, Korupsi, Pencucian Uang. 


\section{PENDAHULUAN}

Praktik pencucian uang hasil dari tindak pidana korupsi yang dilakukan oleh Pejabat Negara di Indonesia telah sangat memberikan dampak yang signifikan terhadap meningkatnya tindak pidana pencucian uang, yang merupakan salah satu upaya yang dilakukan pelaku tindak pidana menghindari dirinya dari jeratan hukum atau pembayaran uang pengganti dengan cara menyembunyikan atau mengaburkan hasil kejahatannya melalui pencucian uang (money laundering). ${ }^{1}$ Hubungan yang erat antara korupsi dengan pencucian uang terungkap dalam praktik penegakan hukum yang dilakukan oleh Komisi Pemberantasan Korupsi. Hal itu tercermin dalam beberapa perkara penting yang diajukan, dibuktikan, dan diputus oleh hakim yang berkekuatan hukum tetap maupun yang masih dalam upaya hukum tingkat banding atau tingkat kasasi, dimana pelaku tindak pidana korupsi tidak hanya melakukan korupsi saja tetapi juga melakukan tindak pidana pencucian uang. ${ }^{2}$

Korupsi bukanlah warisan budaya suatu bangsa, korupsi merupakan penyakit kekuasaan yang dapat ditemukan di berbagai kehidupan masyarakat, baik masyarakat kelas bawah, masyarakat kelas menegah dan masyarakat kelas atas, semua telah terjangkit virus korupsi. Tindak pidana korupsi telah menciptakan pemerintahan yang irasional dan pemerintahan yang didorong oleh keserakahan. Selama ada kekuasaan, maka di situ berpotensi terjadi korupsi. Lord Acton pernah membuat sebuah ungkapan yang menghubungkan antara "Korupsi" dengan "Kekuasaan", yakni "Power tends to corrupt, and absolute power corrupts absolutely", bahwa "Kekuasaan cenderung untuk korupsi dan kekuasaan yang absolute cenderung korupsi absolute". 3

Adanya ungkapan di atas disebabkan realitas saat ini menunjukkan memang benar seperti itu. Kekuasaan yang absolut cenderung koruptif, apalagi jika tidak ada transparansi, akuntabilitas dan check and balances. Untuk itu dalam sistem peradilan pidana perkara pemberantasan tindak pidana korupsi merupakan prioritas utama. Hal ini dapat dilihat dalam Pasal 25 Undang-Undang Nomor 31 Tahun 1999 tentang Pemberantasan Tindak Pidana Korupsi yang menentukan bahwa "penyidikan,

1 Laode M. Syarif dan Didik E. Purwoleksono. Hukum Anti Korupsi, Jakarta: The Asia Foundation, 2012, h. 243

2 Yudi Kristiana, Pemberantasan Tindak Pidana Pencucian Uang, Perspektif Hukum Progresif, Yogyakarta: Thafa Media, 2015, hlm 4.

3 Ermansjah Djaja, Memberantas Korupsi Bersama KPK; Komisi Pemberantasan Korupsi; Kajian Yuridis Normative UU Nomor 31 Tahun 1999 Junto UU Nomor 20 Tahun 2001 Versi UU Nomor 30 Tahun 2002, Jakarta: Sinar Grafika, 2009, h. 1. 
penuntutan, dan pemeriksaan di sidang pengadilan dalam perkara tindak pidana korupsi harus didahulukan dari perkara lain guna penyelesaian secepatnya".

Seiring perkembangan dan kemajuan zaman, para pelaku tindak pidana korupsi pun semakin meningkatkan cara dan modus operandinya, baik dalam proses melakukan tindak pidana korupsi maupun dalam proses menyembunyikan atau menyamarkan asal usul dari harta kekayaannya. Salah satunya dengan cara yang selama ini dikenal dengan istilah pencucian uang (money laundering). Pencucian uang (Money Laundering) adalah suatu upaya perbuatan untuk menyembunyikan atau menyamarkan asal usul uang/dana atau harta kekayaan hasil tindak pidana melalui berbagai transaksi keuangan agar uang atau harta kekayaan tersebut tampak seolah-olah berasal dari kegiatan yang sah/legal. ${ }^{4}$

Penempatan tindak pidana korupsi sebagai tindak pidana asal (predicate crime), merupakan pendapat dari pembentuk undang-undang yang memandang bahwa korupsi merupakan persoalan bangsa yang paling mendesak dalam penanganannya. Sistem peradilan pidana selama ini, pada tindak pidana pencucian uang tidak dibuktikan terlebih dahulu tindak pidana asalnya (predicate crime). Penuntut Umum dalam mengajukan dakwaan pencucian uang lepas dari tindak pidana asal, tidak betul-betul dibuktikan tindak pidana asalnya. Namun belakangan ini Penuntut Umum Komisi Pemberantasan Korupsi telah menggabungkan perkara tindak pidana korupsi dengan tindak pidana pencucian uang. Jika pun ada terdakwa yang lolos dari dakwaan tindak pidana korupsi bukan berarti dia dapat lolos dari jeratan tindak pidana pencucian uang.

Penggabungan perkara merupakan salah satu bagian yang krusial dalam penanganan tindak pidana pencucian uang. Penggabungan perkara yang dimaksudkan di sini adalah penggabungan perkara antara tindak pidana asal, khususnya tindak pidana korupsi dengan tindak pidana pencucian uang. Penggabungan perkara itu bisa terjadi ditingkat penyidikan maupun penuntutan/persidangan.

Disisi lain dengan kehadiran Undang-Undang Nomor 8 Tahun 2010 juga menimbulkan pemahaman yang terlanjur diyakini kebenarannya walaupun belum tentu sepenuhnya benar, ${ }^{5}$ yaitu Penuntut Umum pada Komisi Pemberantasan Korupsi dianggap baru bisa melakukan penyidikan dan penuntutan tindak pidana pencucian uang dalam hal sedang menangani tindak pidana korupsi yang kemudian menemukan tindak pidana 
pencucian uang yang predicat crime-nya tindak pidana korupsi yang kemudian membawa konsekuensi seolah-olah Komisi Pemberantasan Korupsi tidak bisa mengajukan tindak pidana pencucian uang secara terpisah dari tindak pidana asalnya.

Beberapa putusan hakim terkait penggabungan perkara tindak pidana korupsi dengan tindak pidana pencucian uang yang dilakukan oleh Komisi Pemberantasan Korupsi terkadang terjadi perbedaan pendapat (dissenting opinion) oleh majelis hakim dalam memutuskan perkara, sehingga ke depannya dikhawatirkan akan bebasnya pelaku tindak pidana korupsi dan pelaku tindak pidana pencucian uang dari jeratan hukum, padahal jika ditelisik lebih jauh hal ini mengindikasikan bahwa keduanya merupakan dua tindak pidana yang dilakukan secara bersama-sama dalam waktu tertentu.

Berdasarkan uraian singkat di atas maka rumusan masalah dalam tulisan ini adalah: "Bagaimanakah kewenangan penyidikan oleh Komisi Pemberantasan Korupsi dalam penggabungan perkara antara tindak pidana korupsi dan tindak pidana pencucian uang di Indonesia?"

\section{METODE PENELITIAN}

Jenis penelitian yang digunakan dalam penulisan ini adalah penelitian hukum normatif. Dalam penelitian ini penulis melakukan penelitian melalui telaah peraturan perundangundangan dan bahan hukum yang berhubungan dengan penulisan ini. Metode penelitian normatif, yaitu penelitian yang menggunakan bentuk legis positivis yang menyatakan bahwa hukum adalah identik dengan norma-norma tertulis yang dibuat dan diundangkan oleh lembaga-lembaga atau pejabat yang berwenang. Selain itu bentuk ini juga memandang hukum sebagai sistem normatif yang bersifat otonom, tertutup dan terlepas dari kehidupan masyarakat. Penelitian hukum normatif adalah suatu proses untuk menemukan suatu aturan hukum, prinsip-prinsip hukum, maupun doktrin-doktrin hukum guna menjawab isu hukum yang dihadapi. 6

\section{ANALISIS DAN PEMBAHASAN}

\section{Tinjauan Umum Tentang Concursus (Perbarengan/Penggabungan)}

Perbarengan merupakan terjemahan dari concursus atau Samenloop, ada juga yang menerjemahkannya dengan istilah gabungan. Pada dasarnya yang dimaksud dengan

6 Peter Mahmud Marzuki. Penelitian Hukum. Jakarta: Prenada Media Group, 2014, h. 130. 
perbarengan adalah terjadinya dua atau lebih tindak pidana yang dilakukan oleh satu orang yang mana tindak pidana yang pertama belum dijatuhi pidana. Antara tindak pidana awal dengan tindak pidana berikutnya belum dibatasi oleh suatu putusan hakim.

Syarat-syarat yang harus dipenuhi untuk dapat dinyatakan adanya perbarengan adalah: ${ }^{7}$

a. Adanya dua atau lebih tindak pidana yang dilakukan sebagaimana dirumuskan dalam perundang-undangan;

b. Dua atau lebih tindak pidana tersebut dilakukan oleh satu orang atau dua orang atau lebih dalam rangka penyertaan;

c. Dua atau lebih tindak pidana tersebut belum ada yang diadili;

d. Bahwa dua atau lebih tindak pidana tersebut akan diadili sekaligus.

Ilmu hukum pidana mengenal beberapa bentuk perbarengan/penggabungan (concursus), yaitu:

a. Concursus idealis (eendaaadsche samanloop). Concursus idealis terjadi apabila seseorang melakukan satu perbuatan dan ternyata perbuatan tersebut melanggar beberapa ketentuan hukum pidana. Artinya, dengan tindakan yang sama telah menimbulkan terjadinya tindak pidana lain. Hal ini diatur dalam Pasal 63 KUHP yang berbunyi sebagai berikut:

(1) Jika satu perbuatan masuk dalam lebih dari satu ketentuan pidana, maka yang dikenakan hanya salah satu di antara aturan-aturan itu, jika berbeda-beda yang dikenakan yang memuat ancaman pidana pokok yang paling berat.

(2) Jika suatu perbuatan masuk dalam suatu aturan pidana yang umum, diatur pula dalam aturan pidana yang khusus, maka hanya yang itulah yang diterapkan.

Pendapat Simons yang menyatakan di dalam suatu samenloop itu orang harus membedakan apakah si pelaku hanya melakukan satu tindakan, diartikan menurut arti yang sebenarnya, jadi sebagai suatu pelaksanaan secara material ataupun ia telah melakukan beberapa tindakan. ${ }^{8}$

b. Concursus Realis (meerdaadsche samenloop), Concursus realis terjadi apabila seseorang sekaligus merealisasikan beberapa perbuatan. Hal ini diatur dalam Pasal 65-71 KUHP.

Pasal 65 KUHP berbunyi sebagai berikut:

7 Adami Chazawi, Pelajaran Hukum Pidana, Bagian 2; Penafsiran Hukum Pidana, Dasar Peniadaan, Pemberatan \& Peringanan, Kejahatan Aduan, Perbarengan \& Ajaran Kausalitas. Jakarta: PT. Raja Grafindo Persada, 2008, h. 46

8 P. A. F. Lamintang, Dasar-dasar Hukum Pidana Indonesia,Bandung: PT. Citra Aditya Bakti, 1997, hlm 678 
(1) Dalam hal perbarengan beberapa perbuatan yang harus dipandang sebagai perbuatan yang berdiri sendiri sehingga merupakan beberapa kejahatan, yang diancam dengan pidana pokok yang sejenis, maka dijatuhkan hanya satu pidana

(2) Maksimum pidana yang dijatuhkan ialah jumlah maksimum pidana yang diancam terhadap perbuatan itu, tetapi tidak boleh lebih dari maksimum pidana yang terberat ditambah sepertiga.

Pasal 66 KUHP berbunyi sebagai berikut:

(1) Dalam hal perbarengan beberapa perbuatan yang masing-masing harus dipandang sebagai perbuatan yang berdiri sendiri sehingga merupakan beberapa kejahatan, yang diancam dengan pidana pokok yang tidak sejenis, tetapi jumlahnya tidak boleh melebihi maksimum pidana yang terberat ditambah sepertiga.

(2) Pidana denda dalam hal itu dihitung menurut lamanya maksimum pidana kurungan pengganti yang ditentukan untuk perbuatan itu.

Pasal 67 KUHP berbunyi sebagai berikut:

Jika orang dijatuhi pidana mati atau pidana penjara seumur hidup, di samping itu tidak boleh dijatuhi pidana lain lagi kecuali pencabutan hakhak tertentu, perampasan barang-barang yang telah disita sebelumnya, dan pengumuman putusan hakim.

Pasal 68 KUHP berbunyi sebagai berikut:

(1) Berdasarkan hal-hal dalam Pasal 65 dan 66, tentang pidana tambahan berlaku aturan sebagai berikut:

1. Pidana-pidana pencabutan hak yang sama dijadikan satu yang lamanya paling sedikit dua tahun dan paling banyak lima tahun melebihi pidana pokok yang dijatuhkan. Jika pidana pokok hanya pidana denda saja, maka lamanya pencabutan hak paling sedikit dua tahun dan paling lama lima tahun.

2. Pidana-pidana pencabutan hak yang berlainan dijatuhkan sendiri-sendiri tanpa dikurangi.

3. Pidana-pidana perampasan barang-barang tertentu, begitu pula halnya dengan pidana kurungan pengganti karena barangbarang tidak diserahkan, dijatuhkan sendiri-sendiri tanpa dikurangi.

(2) Pidana kurungan pengganti jumlahnya tidak boleh melebihi delapan bulan.

Pasal 69 KUHP berbunyi sebagai berikut:

1. Perbandingan beratnya pidana pokok yang tidak sejenis ditentukan menurut urutan dalam Pasal 10.

2. Jika hakim memilih antara beberapa pidana pokok, maka dalam perbandingan hanya yang terberatlah yang dipakai.

3. Perbandingan beratnya pidana-pidana pokok yang sejenis ditentukan menurut maksimumnya masing-masing. 
4. Perbandingan lamanya pidana-pidana pokok, baik yang sejenis maupun yang tidak sejenis, juga ditentukan menurut maksimalnya masing-masing.

Pasal 70 KUHP berbunyi sebagai berikut:

(1) Jika perbarengan seperti yang dimaksudkan dalam Pasal 65 dan 66, baik perbarengan pelanggaran dengan kejahatan, maupun pelanggaran dengan pelanggaran, maka untuk tiap-tiap pelanggaran dijatuhkan pidana sendiri-sendiri tanpa dikurangi.

(2) Mengenai pelanggaran, jumlah lamanya pidana kurungan dan pidana kurungan pengganti paling banyak satu tahun empat bulan, sedangkan jumlah lamanya pidana kurungan pengganti paling banyak delapan bulan.

c. Perbuatan Berlanjut (voortgezette handeling)

Perbuatan berlanjut terjadi apabila seseorang melakukan perbuatan yang sama beberapa kali, dan di antara perbuatan-perbuatan itu terdapat hubungan yang sedemikian eratnya sehingga rangkaian perbuatan itu harus dianggap sebagai perbuatan lanjutan. Hal ini diatur dalam Pasal 64 KUHP yang berbunyi sebagai berikut:

(1) Jika antara beberapa perbuatan, meskipun masing-masing merupakan kejahatan atau pelanggaran, ada hubungan sedemikian rupa sehingga harus dipandang sebagai satu perbuatan berlanjut, maka hanya diterapkan yang memuat ancaman pidana pokok yang paling berat

(2) Demikian pula hanya dikenakan satu aturan pidana, jika orang dinyatakan bersalah melakukan pemalsuan atau perusakan mata uang, dan menggunakan barang yang dipalsukan atau dirusak itu.

Akan tetapi jika orang yang melakukan kejahatan-kejahatan tersebut dalam Pasal 364, 373, 379, dan 407 ayat (1) sebagai perbuatan berlanjut dan nilai kerugian yang ditimbulkan jumlahnya melebihi dari tiga ratus tujuh puluh lima rupiah, maka ia dikenakan aturan pidana tersebut dalam Pasal 362, 372, 378, dan 406.

\section{Tinjauan Umum Tentang Tindak Pidana Korupsi}

Korupsi berasal dari kata latin corruption atau korruptie. Kemudian, muncul dalam bahasa Inggris dan Perancis corruption, dalam bahasa Belanda korruptie, selanjutnya dalam bahasa Indonesia dengan sebutan korupsi. Kata corruptio memiliki makna yang sangat 
luas namun juga disamakan artinya dengan penyuapan seperti yang disebut dalam ensiklopedia grote winkler prins . ${ }^{9}$

Definisi tentang korupsi dapat dipandang dari berbagai aspek, bergantung pada disiplin ilmu yang dipergunakan sebagaimana dikemukakan oleh Benveniste dalam Suyatno, korupsi didefinisikan empat jenis ${ }^{10}$ yakni: Discretionary corruption, ialah korupsi yang dilakukan karna adanya kebebasan dalam menentukan kebijaksanaan, sekali pun nampaknya bersifat sah, bukanlah praktik-praktik yang dapat diterima oleh para anggota organisasi; Illegal corruption, ialah suatu jenis tindakan yang bermaksud mengacaukan bahasa atau maksud-maksud hukum, peraturan dan regulasi tertentu; Mercenery corruption, ialah jenis tindak pidana korupsi yang dimaksud untuk memperoleh keuntungan pribadi, melalui penyalahgunaan wewenang dan kekuasaan; serta Ideological corruption, ialah jenis korupsi ilegal maupun discretionary yang dimaksudkan untuk mengejar tujuan kelompok. Kata korupsi ditemukan pula dalam The Lexicon Webster Dictionary yang berarti; kebusukan, keburukan, kebejatan, ketidakjujuran, dapat disuap, tidak bermoral, penyimpangan dari kesucian, kata-kata atau ucapan yang menghina atau memfitnah. 11

Tindak Pidana Korupsi Dalam Hukum Positif diatur dalam Undang-Undang Nomor 31 Tahun1999 Tentang Pemberantasan Tindak Pidana Korupsi Sebagaimana Telah Diubah Dengan Undang-Undang Nomor 20 Tahun 2001 Tentang Perubahan Atas UndangUndang Nomor 31 Tahun 1999 Tentang Pemberantasan Tindak Pidana Korupsi. 12

Karakteristik yuridis yang terkandung dalam undang-undang tindak pidana korupsi, secara keseluruhan telah menggambarkan adanya dinamika pembaharuan hukum pidana dalam pemberantasan tindak pidana korupsi. Dalam undang-undang tersebut dapat dilihat bahwa pembentuk undang-undang telah secara sistematis merumuskan kurang lebih tiga puluh jenis korupsi ke dalam berbagai delik tentang tindak pidana korupsi yang dijabarkan dalam tiga belas Pasal yang kemudian dikelompokkan ke dalam tujuh jenis tindak pidana korupsi. ${ }^{13}$ Ketujuh jenis tindak pidana korupsi itu, yaitu: ${ }^{14}$ Tindak pidana korupsi yang berkaitan dengan merugikan keuangan negara; Tindak pidana

\footnotetext{
Laode M. Syarif, Hukum Anti Korupsi, Op. Cit, h. 14

Ermansjah Djaja, Memberantas Korupsi Bersama KPK..... Op. Cit, h. 5

Ibid. h. 7

Laode M. Syarif, Hukum Anti Korupsi, Op. Cit, h. 19

Ibid. h. 21

Ibid. h. 21
} 
korupsi yang berkaitan dengan suap-menyuap; Tindak pidana korupsi yang berkaitan dengan penggelapan dalam jabatan; Tindak pidana korupsi yang berkaitan dengan pemerasan; Tindak pidana korupsi yang berkaitan dengan perbuatan curang; Tindak pidana korupsi yang berkaitan dengan benturan kepentingan dalam pengadaan; Tindak pidana yang berkaitan dengan Gratifikasi.

\section{Tinjauan Umum Tentang Tindak Pidana Pencucian Uang}

Pencucian uang atau juga dikenal dengan money laundering adalah perbuatan menyembunyikan atau menyamarkan asal-usul harta kekayaan melalui berbagai transaksi keuangan sehingga seolah-olah diperoleh dengan cara yang sah. Lebih lanjut dikemukakan bahwa tujuan utama dari pencucian uang adalah menyamarkan bahwa harta kekayaan itu diperoleh dari tindak pidana, sehingga dapat menikmati hasilnya untuk kegiatan yang sah. 15

Pengertian tindak pidana pencucian uang yang lain adalah sebagaimana dijumpai dalam Black Law Dictionary ${ }^{16}$.

Money laundering is term applied to taking money gotten illegally and washing or laundering it so appears to have been gotten legally. Artinya: "pencucian uang adalah istilah yang diterapkan untuk mengambil uang dan mendapatkannya secara ilegal dan pencucian tersebut telah tampak dimulai secara melawan hukum".

Berdasarkan pengertian ini terlihat bahwa money laundering adalah istilah yang digunakan untuk menggambarkan perolehan uang secara tidak sah dan menggunakannya seolah-olah tampak diperoleh secara sah.

Money Laundering merupakan suatu proses yang dengan cara itu aset, terutama aset tunai yang diperoleh dari tindak pidana dimanipulasi sedemikian rupa sehingga aset tersebut seolah-olah berasal dari sumber yang sah. Tindak pidana pencucian uang merupakan tindak pidana lanjutan (predicate crime), atau yang dikenal dengan istilah kejahatan asal. Hasil tindak pidana dimaksudkan adalah harta kekayaan yang diperoleh dari tindak pidana. Korupsi menjadi sumber utama dari perolehan uang yang tidak sah sehingga dapat diartikan bahwa korupsi menjadi salah satu sumber utama predicate crime dalam pencucian uang.

Money laundering di Indonesia diatur dalam hukum positif yaitu sejak lahirnya Undang-Undang Nomor 15 Tahun 2002 yang kemudian disempurnakan dengan Undang-

15 Yudi Kristiana, Pemberantasan Tindak Pidana Pencucian Uang.... Op. Cit, h. 17.

16 Ibid. h. 18. 
Undang Nomor 25 Tahun 2003, yang telah diubah dengan Undang-Undang Nomor 8 Tahun 2010 Tentang Pencegahan dan Pemberantasan Tindak Pidana Pencucian Uang. Memberikan definisi pada Pasal 1 Angka 1 bahwa:

"Pencucian uang adalah segala perbuatan yang memenuhi unsur-unsur tindak pidana sesuai dengan ketentuan dalam undang-undang ini”.

Pengertian pelaku tindak pidana pencucian uang menurut Undang-Undang Nomor 8 Tahun 2010 pada Pasal 3 sebagai berikut:

"Setiap orang yang menempatkan, mentransfer, mengalihkan, membelanjakan, membayarkan, menghibahkan, menitipkan, membawa keluar negeri, mengubah bentuk, menukarkan dengan mata uang atau surat berharga atau perbuatan lain atas harta kekayaan yang diketahui atau patut diduganya merupakan hasil tindak pidana sebagaimana dimaksud dalam Pasal 2 ayat (1) dengan tujuan menyembunyikan atau menyamarkan asal-usul harta kekayaan dipidana dengan pidana penjara paling lama 20 (dua puluh) tahun dan denda paling banyak Rp. 10 . 000. 000. 000,00 (sepuluh miliar rupiah)."

Untuk melaksanakan tindak pidana pencucian uang, para pelaku memiliki metode tersendiri dalam melakukan tindak pidana tersebut. Walaupun setiap pelaku sering melakukan dengan metode yang bervariasi tetapi secara garis besar metode pencucian uang dapat dibagi menjadi tiga tahap yaitu placement, layering, dan integration. Walaupun ketiga metode tersebut dapat berdiri sendiri atau mandiri terkadang dan tidak menutup kemungkinan ketiga metode tersebut dilakukan secara bersamaan. Tahap-tahap yang dimaksud yaitu: 17

Pertama, tahap placement yaitu upaya untuk menempatkan harta kekayaan yang dihasilkan dari kejahatan atau diperoleh secara tidak sah ke dalam sistem keuangan, misal dengan menempatkan di bank, menyetorkan sebagai pembayaran kredit, menyeludupkan dalam bentuk tunai, membiayai kegiatan atau usaha yang sah, membeli barang-barang yang berharga dan sebagainya.

Kedua, tahap layering yaitu upaya untuk memisahkan hasil tindak pidana dari sumbernya yaitu tindak pidananya melalui beberapa tahap transaksi keuangan untuk menyembunyikan atau menyamarkan asal-usul harta kekayaan. Hal ini dilakukan misalnya dengan mentransfer dari satu bank ke bank lain termasuk antar wilayah atau negara menggunakan simpanan tunai sebagai agunan untuk mendukung transaksi yang sah, memindahkan uang tunai lintas negara, dan lainlain.

Ketiga, tahap integration yaitu upaya pada harta yang telah tampak sah, baik untuk dinikmati secara langsung maupun secara tidak langsung, diinvestasikan ke dalam berbagai bentuk kekayaan material maupun keuangan, dipergunakan untuk membiayai kegiatan bisnis yang sah, ataupun untuk membiayai kembali tindak pidana. Dalam melakukan pencucian uang pelaku tidak mempertimbangkan hasil

17 Yudi Kristiana, Pemberantasan Tindak Pidana Pencucian Uang..... Op. Cit. h. 18. 
yang akan diperoleh, dan besarnya biaya yang harus dikeluarkan karena tujuan utamanya adalah untuk menyamarkan atau menghilangkan asal-usul uang sehingga hasil tindak pidana akhirnya dapat dinikmati atau digunakan secara aman.

Ketiga kegiatan tersebut di atas dapat terjadi secara terpisah atau stimulan, namun secara umum dilakukan secara tumpang tindih. Modus operandi pencucian uang dari waktu ke waktu semakin kompleks dengan menggunakan technology dan rekayasa keuangan yang cukup rumit. Hal itu terjadi baik pada tahapan placement, layering, maupun integration sehingga penanganannya pun menjadi semakin sulit dan membutuhkan peningkatan kemampuan (capacity building) secara sistematis dan berkesinambungan. Pemilihan modus operandi pencucian uang bergantung pada kebutuhan pelaku tindak pidana.

\section{Bentuk Penggabungan Perkara Tindak Pidana Korupsi Dengan Tindak Pidana Pencucian Uang Dalam Sistem Peradilan Pidana Di Indonesia}

Kitab Undang-Undang Hukum Acara Pidana telah mengatur tentang penggabungan perkara, namun penggabungan perkara yang diatur hanya dalam tahap penuntutan, bukan dalam tahap penyidikan. Selanjutnya pengaturan penggabungan perkara tahap penuntutan ini menjadi kerangka acuan dalam rangka penyidikan, karena penyidikan akan bermuara pada penuntutan. Harus diakui bahwa keterbatasan pengaturan penggabungan perkara menurut Kitab Undang-Undang Hukum Acara Pidana belum mengakomodasi kompleksitas perkembangan penanganan perkara seperti yang sekarang terjadi misalnya kekhususan penanganan perkara baik tahap penyidikan maupun penuntutan termasuk munculnya lembaga seperti Komisi Pemberantasan Korupsi. ${ }^{18}$

Adapun kriteria tindak pidana korupsi yang menjadi kewenangan Komisi Pemberantasan Korupsi adalah tindak pidana korupsi yang diatur dalam Pasal 11 UndangUndang Tindak Pidana Korupsi:

a. Melibatkan aparat penegak hukum penyelenggara negara dan orang lain yang ada kaitannya dengan tindak pidana korupsi yang dilakukan oleh aparat penegak hukum atau penyelenggara negara;

b. Mendapat perhatian yang meresahkan masyarakat;

c. Menyangkut kerugian negara paling sedikit Rp. 1. 000. 000. 000,00 (satu milyar rupiah).

18 Yudi Kristiana, Pemberantasan Tindak Pidana Pencucian Uang.... Op. Cit, h. 213. 
Penuntut umum dapat melakukan penggabungan perkara dan membuatnya dalam satu surat dakwaan, apabila pada waktu yang sama atau hampir bersamaan ia menerima beberapa berkas perkara dalam hal:

a. Beberapa tindak pidana yang dilakukan oleh seorang yang sama dan kepentingan pemeriksaan tidak menjadikan halangan terhadap penggabungannya;

b. Beberapa tindak pidana yang bersangkut-paut satu dengan yang lain;

c. Beberapa tindak pidana yang tidak bersangkut-paut satu dengan yang lainnya, akan tetapi yang satu dengan yang lain itu ada hubungannya, yang dalam hal ini penggabungan tersebut perlu bagi kepentingan pemeriksaan.

Tindak pidana yang dianggap mempunyai sangkut paut satu dengan yang lainnya, yaitu sebagaimana dijelaskan dalam Penjelasan Pasal 141 huruf b Kitab Undang-Undang Hukum Acara Pidana. Tindak pidana yang memiliki sangkut paut dengan yang lainnya apabila tindak pidana tersebut dilakukan:

1. Oleh lebih dari seorang yang bekerja sama dan dilakukan pada saat yang bersamaan.

2. Oleh lebih dari seorang pada saat dan tempat yang berbeda, akan tetapi merupakan pelaksanaan dari permufakatan jahat yang dibuat oleh mereka sebelumnya.

3. Oleh seorang atau lebih dengan maksud mendapatkan alat yang akan dipergunakan untuk melakukan tindak pidana lain atau menghindarkan diri dari pemidanaan karena tindak pidana lain.

Dasar hukum yang digunakan oleh Komisi Pemberantasan Korupsi dalam menyidik perkara Tindak Pidana pencucian Uang adalah Undang-Undang Nomor 46 Tahun 2009 Tentang Pengadilan Tindak Pidana Korupsi, yang pada Pasal 6 mengatur kewenangan Pengadilan Tindak Pidana Korupsi yaitu memeriksa, mengadili dan memutus perkara tindak pidana korupsi, tindak pidana pencucian uang yang tindak pidana asalnya tindak pidana korupsi dan tindak pidana lain yang secara tegas dalam undang-undang lain ditentukan sebagai tindak pidana korupsi.

Ketentuan Pasal 74 Undang-Undang Nomor 8 Tahun 2010 Tentang Tindak Pidana Pencucian Uang juga merupakan ketentuan yang memiliki relevansi dengan penggabungan perkara yang berbunyi:

Penyidikan tindak pidana pencucian uang dilakukan oleh penyidik tindak pidana asal sesuai dengan ketentuan hukum acara dan ketentuan peraturan perundangundangan, kecuali ditentukan lain menurut undang-undang ini. 
Terkait tindak pidana asal yang dihubungkan dengan tindak pidana pencucian uang pada tahap penyidikan maupun penuntutan, maka ketentuan Pasal 75 Undang-Undang Nomor 8 Tahun 2010 tersebut berbunyi:

Dalam hal penyidik menemukan bukti permulaan yang cukup terjadinya tindak pidana pencucian uang dan tindak pidana asal, penyidik menggabungkan penyidikan tindak pidana asal dengan penyidikan tindak pidana pencucian uang dan memberitahukannya kepada PPATK.

Sistem peradilan di Indonesia mengenal tiga bentuk penggabungan perkara antara tindak pidana pencucian uang dan tindak pidana asal baik pada tahap penyidikan maupun tahap penuntutan yaitu: 19

Bentuk pertama, dalam hal penyidik sedang menyidik tindak pidana pencucian uang, kemudian dalam perkembangannya penyidik dapat menelusuri tindak pidana asalnya. Bentuk kedua, dalam hal kemunculan tindak pidana pencucian uang diketahui setelah berlangsungnya penyidikan tindak pidana asal. Artinya penyidik sedang bekerja melakukan penyidikan tindak pidana asal, misalnya tindak pidana korupsi, baru kemudian di tengah perjalanan menemukan tindak pidana pencucian uang. Bentuk ketiga, dalam hal penyidik sedang menyidik tindak pidana asal, kemudian di tengah perjalanan selain menemukan tindak pidana pencucian uang yang predicate crime-nya merupakan tindak pidana yang sedang disidik tersebut, juga menemukan tindak pidana pencucian uang yang lain yang predicate crime-nya di luar dari tindak pidana yang sedang disidik.

Ketentuan Pasal 69 Undang-Undang Nomor 8 Tahun 2010 Tentang Tindak Pidana Pencucian Uang mengatur bahwa untuk dapat dilakukan penyidikan tindak pidana pencucian uang, tidak wajib dibuktikan terlebih dahulu tindak pidana asalnya. Bunyi ketentuan Pasal 69 tersebut sebagai berikut:

Untuk dapat dilakukan penyelidikan, penuntutan, dan pemeriksaan di sidang pengadilan terhadap tindak pidana pencucian uang tidak wajib dibuktikan terlebih dahulu tindak pidana asalnya.

Ketentuan ini berarti bahwa tindak pidana pencucian uang adalah tindak pidana berdiri sendiri yang bisa disidik tanpa harus disidik terlebih dahulu tindak pidana asalnya, tanpa harus dituntut dan dibawa ke pengadilan untuk dibuktikan terlebih dahulu tindak pidana asalnya. Misalnya atas tindak pidana pencucian uang yang tindak pidana asalnya berupa tindak pidana korupsi, maka untuk dapat dilakukan penyidikan atas perkara

19 Ibid. h. 215. 
tindak pidana pencucian uangnya tidak harus menunggu dibuktikan tindak pidana asalnya yang berupa tindak pidana korupsi.

Demikian hal karena ketentuan Pasal 69 sifatnya kurang tegas, yaitu adanya penggunaan kata-kata "tidak wajib dibuktikan terlebih dahulu" maka dalam praktik penanganan tindak pidana pencucian uang oleh Komisi Pemberantasan Korupsi memberikan ruang perdebatan, misalnya ada yang mengartikan bahwa karna tidak wajib dibuktikan terlebih dahulu berarti sesungguhnya tetap perlu dibuktikan. ${ }^{20}$

Implikasi dari ketentuan Pasal 69 yang menyebutkan "untuk dapat dilakukan penyidikan, penuntutan dan pemeriksaan di sidang pengadilan terhadap tindak pidana pencucian uang tidak wajib dibuktikan terlebih dahulu tindak pidana asalnya" adalah untuk dapat dilakukan penyidikan terhadap tindak pidana pencucian uang maka terdapat dua kemungkinan: pertama, dalam hal tindak pidana pencucian uang disidangkan dalam satu perkara tersendiri tanpa disertakan tindak pidana asalnya, maka dengan demikian tindak pidana asalnya tidak perlu dibuktikan terlebih dahulu. Sedangkan kemungkinan kedua, adalah dalam hal penanganan tindak pidana pencucian uang juga ditemukan tindak pidana asalnya, maka keduanya digabungkan ke dalam satu berkas perkara, kemudian dilimpahkan dalam satu dakwaan yang kemudian dalam pembuktiannya di persidangan keduanya akan dibuktikan.

\section{KESIMPULAN}

Komisi Pemberantasan Korupsi mempunyai kewenangan melakukan penyidikan dan penuntutan terhadap gabungan perkara tindak pidana korupsi dengan tindak pidana pencucian uang pada umumnya, dengan mengacu pada dua bentuk penggabungan perkara. Bentuk penggabungan pertama didasarkan pada ketentuan Pasal 74, Pasal 75 Undang-Undang Nomor 8 Tahun 2010 Tentang Tindak Pidana Pencucian Uang, dan pada ketentuan Pasal 6 Undang-Undang Nomor 46 Tahun 2009 Tentang Pengadilan Tindak Pidana Korupsi, maka penggabungan perkara dalam hal penyidik sedang menyidik tindak pidana asal, kemudian dalam perkembangannya penyidik menemukan tindak pidana pencucian uang yang tindak pidana asalnya tindak pidana yang sedang disidik. Bentuk penggabungan perkara yang kedua berdasarkan Pasal 69 Undang-Undang Nomor 8 Tahun 2010 Tentang Tindak Pidana Pencucian Uang dikaitkan dengan bentuk sebelumnya maka

20 http://www.hukumonline.com/berita/baca/lt52f0d81c6ed50/grey-area-penanganan-tppu-bagian-2 diakases pada tanggal 19 Maret 2017 
penggabungan perkara dalam hal penyidik sedang menyidik tindak pidana asal, kemudian di tengah perjalanan selain menemukan tindak pidana pencucian uang yang predicate crime-nya merupakan tindak pidana yang sedang disidik tersebut, juga menemukan tindak pidana pencucian uang yang lain yang predicate crime-nya di luar dari tindak pidana yang sedang disidik. Penggabungan perkara dalam penuntutan menggunakan dakwaan kumulatif dengan pendekatan concursus.

\section{Daftar Pustaka}

\section{Sumber Buku:}

Chazawi, Adami, Pelajaran Hukum Pidana, Bagian 2; Penafsiran Hukum Pidana, Dasar Peniadaan, Pemberatan \& Peringanan, Kejahatan Aduan, Perbarengan \& Ajaran Kausalitas. Jakarta: PT. Raja Grafindo Persada, 2008 , Pelajaran Hukum Pidana, Bagian 1; Stelsel Pidana, Teori-Teori Pemidanaan \& Batas Berlakunya Hukum Pidana, Jakarta: PT. Raja Grafindo Persada, 2002.

Djaja, Ermansjah, Memberantas Korupsi Bersama KPK; Komisi Pemberantasan Korupsi;Kajian Yuridis Normative UU Nomor 31 Tahun 1999 Junto UU Nomor 20 Tahun 2001 Versi UU Nomor 30 Tahun 2002, Jakarta: Sinar Grafika, 2009.

Kristiana, Yudi, Pemberantasan Tindak Pidana Pencucian Uang, Perspektif Hukum Progresif. Yogyakarta: Thafa Media, 2015.

Lamintang, P. A. F., Dasar-Dasar Hukum Pidana Indonesia, Bandung: PT. Citra Aditya Bakti, 1997.

Marzuki, Peter Mahmud, Penelitian Hukum, Jakarta: Prenada Media Group, 2014.

Syarif, Laode M dan Didik E. Purwoleksono, Hukum Anti Korupsi, Jakarta: The Asia Foundation, 2012.

\section{Sumber Peraturan Perundang-Undangan:}

Undang-Undang Nomor 1 Tahun 1946 Tentang Peraturan Hukum Pidana (Lembaran Negara Tahun 1958 Nomor 127, Tambahan Lembaran Negara Nomor 1660); Undang-Undang Nomor 8 Tahun 1981 Tentang Peraturan Hukum Acara Pidanal Lembaran Negara Tahun 1981 Nomor 76, Tambahan Lembaran Negara Nomor 3258); 
Undang-Undang Nomor 31 Tahun 1999 Tentang Pemberantasan Tindak Pidana Korupsi

(Lembaran Negara Republik Indonesia Tahun 1999 Nomor 140, Tambahan

Lembaran Negara Republik Indonesia Nomor 3874);

Undang-Undang Nomor 20 Tahun 2001 Tentang Perubahan Atas Undang-Undang Nomor

31 Tahun 1999 Tentang Pemberantasan Tindak Pidana Korupsi (Lembaran

Negara Republik Indonesia Tahun 2001 Nomor 134, Tambahan Lembaran Negara

Republik Indonesia Nomor 4150);

Undang-Undang Nomor 30 Tahun 2002 Tentang Komisi Pemberantasan Korupsi

(Lembaran Negara Republik Indonesia Tahun 2002 Nomor 137, Tambahan

Lembaran Negara Republik Indonesia Nomor 4250);

Undang-Undang Nomor 46 Tahun 2009 Tentang Pengadilan Tindak Pidana Korupsi

(Lembaran Negara Republik Indonesia Tahun 2009 Nomor 155, Tambahan

Lembaran Negara Republik Indonesia Nomor 5074);

Undang-Undang Nomor 8 Tahun 2010 Tentang Pencegahan Dan Pemberantasan Tindak

Pidana Pencucian Uang (Lembaran Negara Republik Indonesia Tahun 2010

Nomor 122, Tambahan Lembaran Negara Republik Indonesia Nomor 5164);

\section{Sumber Internet}

http://www.hukumonline.com/berita/baca/lt52f0d3968ed1f/greyarea-penanganantppu-bagian-1 Diakses pada tanggal 19 Maret 2017

http://www.hukumonline.com/berita/baca/lt52f0d81c6ed50/grey-area-penanganantppu-bagian-2 diakases pada tanggal 19 Maret 2017 